\title{
Bladder Fundus
}

National Cancer Institute

\section{Source}

National Cancer Institute. Bladder Fundus. NCI Thesaurus. Code C48939.

The portion of the bladder that is formed by the posterior wall and is located opposite to the bladder opening. 